\title{
GRAPHENE OXIDE AS ANTIMICROBIAL AGAINST TWO GRAM-POSITIVE AND TWO GRAM-NEGATIVE BACTERIA IN ADDITION TO ONE FUNGUS
}

\author{
${ }^{1}$ Roda F. Al-Thani, ${ }^{2}$ Noorunnisa Khanam Patan and ${ }^{2}$ Mariam A. Al-Maadeed \\ ${ }^{1}$ Department of Biological and Environmental Sciences, \\ College of Arts and Sciences, Qatar University, P.O. Box 2713 Doha, Qatar \\ ${ }^{2}$ Center for Advanced Materials, Qatar University, Qatar
}

Received 2014-07-20; Revised 2014-08-29; Accepted 2014-09-08

\begin{abstract}
Graphene based materials have wide potential applications in biology, biomedical, agriculture environmental and biotechnology. Graphene Oxide (GO) is one of those materials and has a promising substance as antimicrobial agents. GO in this study was prepared by a modified Hummers method and was characterized by different techniques for confirmation of formation of GO. To study the antimicrobial activities of GO, it was tested against these microorganisms, one eukaryotic fungus (Candida albicans, $C$. albicans) two Gram negative bacteria (Escherichia coli (E. coli) ATCC 41570 and Pseudomonas aeruginosa (P. aeruginosa) ATCC 25619) and two Gram positive bacteria (Streptococcus faecalis (S. faecalis) ATCC 19433 and Staphylococcus aureus (S. aureus) ATCC 11632). Anti-microbial activity of GO was detected by spectrophotometer as indirect method to measure the growth and viable cell count as direct method. Readings were taken at successive incubated times. Results revealed that GO has antibacterial and anti-fungal activity against microorganisms used in this study. In conculosion the developed GO exhibit excellent antimicrobial property and GO affects more on Gram positive bacteria than Gram negative bacteria and fungi.
\end{abstract}

Keywords: Antimicrobial, Graphene Oxide, Gram Negative Bacteria, Gram Positive Bacteria, Eukaryotic Cells

\section{INTRODUCTION}

Graphene Based Materials (GBMs) include few-layer graphene, graphene nanosheets, graphene oxide and reduced graphene oxide. Graphene comprising of singleatom-thick sheets of sp2- bonded carbon. It is a typical two-dimensional material made of carbon atoms packed densely in a honeycomb crystal lattice (Geim and Novoselov, 2007; Sanchez et al., 2011). Also they have unique electronic and mechanical properties and demonstrate great potential for applications in many areas such as field effect transistors, solar cells, sensors and adsorbent for heavy metal removal (Zhang et al., 2010). Graphene Oxide (GO) is chemically modified graphene, containing hydroxyl, carbonyl and epoxy functional groups, which is obtained by synthesis of graphite with strong oxidizing agents (Alves et al., 2014). Also it has been used as a promising material for preparing new composites (Tang et al., 2013). It is well known that GO and its composites possess anti-microbial properties and have been used as anti-bacterial and antifungal agents (Santos et al., 2012; De Faria et al., 2014).

The effect and interaction of GBMs on microbial cells structure, metabolism and viability has been shown to depend on the materials' concentration, time of exposure and physical-chemical properties, as well as on the characteristics of microorganisms used in the tests (Akhavan and Ghaderi 2010; Hu et al., 2010; Liu et al.,

Corresponding Author: Roda F. Al-Thani, Department of Biological and Environmental Sciences, College of Arts and Sciences, Qatar University, P.O. Box 2713 Doha, Qatar Tel: +974 44034539 Fax: +974 44034531 
2011; De Faria et al., 2014). There are different mode of action of GBM into microbial cells some studies suggests disruption cell wall and membranes because of sharp edges of GO or because of generation of Reactive Oxygen Species (ROS) which may be fatal factor for microbial cells (Chen et al., 2013). GBMs have been tested as antibacterial against food borne pathogens bacteria e.g., E. coli and $S$. aureus (Santos et al., 2012; Liu et al., 2012; Tang et al., 2013); opportunistic pathogens bacteria e.g., P. aerogenosa and Klebseilla sp. (Lim et al., 2012; Bykkam et al., 2013); plant pathogen e.g., Xanthomonas oryzae (Chen et al., 2013) and against fungi e.g., $C$. albicans and $C$. tropical (Li et al., 2013). Also several studies demonstrated and developed an environment friendly, cost effective, simple method and green approaches for the reduction of GO using microbial cells such as E. coli, Shewanella and Yeast (Gurunathan et al., 2013; Wang et al., 2011; Khanra et al., 2012).

In this research study, the GO prepared by modified Hammers method and its antimicrobial activity against one fungus (C. albicans) two prokaryotic bacteria Gramnegative bacilli (E. coli ATCC 41570 and $P$. aeruginosa ATCC 25619) and two prokaryotic bacteria Grampositive cocci (S. feacalis ATCC 19433 and S. aureus ATCC 11632) was tested. Also the effect of incubated time was studied, start after $24 \mathrm{~h}$ incubation for 4 days.

\section{MATERIALS AND METHODS}

\subsection{Preparation of Graphene Oxide (GO)}

GO was prepared from natural graphite flakes by a modified Hummers method (Akhavan and Ghaderi 2012; Shahriary and Athawale 2014; Zheng et al., 2013). Briefly, graphite $(3.0 \mathrm{~g})$ was added to concentrated $\mathrm{H}_{2} \mathrm{SO}_{4}(70 \mathrm{~mL})$ under stirring at room temperature. Then NaNO3 (1.5 g) was added and the mixture was cooled to $0^{\circ} \mathrm{C}$. Under vigorous agitation, $\mathrm{KMnO} 4(9.0 \mathrm{~g})$ was added slowly to keep the temperature of the suspension lower than $20^{\circ} \mathrm{C}$. The mixture was stirred at $35^{\circ} \mathrm{C}$ for $2 \mathrm{~h}$. Then distilled water $(150 \mathrm{~mL})$ was added and the solution was stirred at $90^{\circ} \mathrm{C}$ for $15 \mathrm{~min}$. Additional 500 $\mathrm{mL}$ of distilled water was added and followed by a slow addition of $15 \mathrm{~mL}$ of $\mathrm{H}_{2} \mathrm{O}_{2}(3 \%)$, turning the color of the solution from dark brown to yellow. The mixture was filtered and washed with 1:10 $\mathrm{HCl}$ aqueous solution (250 $\mathrm{mL}$ ) to remove metal ions followed by washing with 200 $\mathrm{mL}$ of distilled water to remove the acid. The resulting solid was dried in air and diluted to get a GO aqueous dispersion $(0.5 \mathrm{wt} \%)$.

\subsection{Structure and Characterization of the Prepared GO}

Structure and characterization of GO was confirmed by four methods include, Powder X-ray diffraction which was carried out by X-ray diffract meter, model Rigaku MiniFlex2. XRD was used to measure the size of the particle; the thermo gram of the graphite and graphene oxide was recorded by Perkin Elmer thermo gravimetric analyzer. Thermo Gravimetric Analysis (TGA) was carried out under nitrogen atmosphere by using TA instrument. The samples were heated from room temperature to $600^{\circ} \mathrm{C}$ at $10^{\circ} \mathrm{C} / \mathrm{min}$. Fourier Transform Infrared spectroscopy (FT-IR) spectral analysis of all samples were cryogenically cooled and powdered. The powders were diluted to $1 \%$ using potassium Bromide $(\mathrm{KBr})$ and pellets were prepared. The FT-IR spectra of the samples were recorded in the 4000$500 \mathrm{~cm}^{-1}$ region on a FT-IR spectrophotometer model 670 (NEXUS) Nicolet in transmittance model with resolution of $4 \mathrm{~cm}^{-1}$ with 34 scans. FT-IR was performed to identify types of chemical bonds, i.e., functional groups in a molecule. The surface morphological analysis of samples was carried out by using a Scanning Electron Microscope (SEM-EDX Philips). Samples were used without any coating for SEM analysis.

\subsection{Antimicrobial Activity of GO}

\subsubsection{Preparations of Microorganism Cells}

The 5 microorganisms used were as follows one eukaryotic fungus (C. albicans) two prokaryotic bacteria Gram negative bacilli (E. coli ATCC 41570 and $P$. aeruginosa ATCC 25619) and two prokaryotic bacteria Gram positive cocci (S. faecalis ATCC 19433 and $S$. aureus ATCC 11632). Microorganisms were cultured on Nutrient Agar (NA) for $24 \mathrm{~h}$. Four to five well isolated colonies from overnight culture were transferred using sterile loop to the tube of sterilized $0.8 \%$ saline solutions $(10 \mathrm{~mL})$. The inoculums was emulsified inside the saline tube to avoid clumping of the cells and incubated at $37^{\circ} \mathrm{C}$ for $10 \mathrm{~min}$ to adjust the inoculums standard to a 0.5 McFarland which equals approximately $108 \mathrm{CFU} / \mathrm{mL}$.

\subsubsection{Agar Diffusion}

Within 10 min of preparing the adjusted inoculums, a sterile cotton swab was dipped into the inoculums (separately for the 5 selected microorganisms) and streaked over the entire surface of the 5 nutrient agar plates. Subsequently, GO disk (5 $\mathrm{mm}$ in diameter) was placed on surface of each inoculated plate using sterile 
forceps. After application, insure that the disk has made complete contact with the agar surface by touching the top of the disk with forceps. Also a piece of filter paper is immersed into GO solution and placed over the agar previously inoculated with the microorganisms. The plates are then incubated at $37^{\circ} \mathrm{C}$ for $24 \mathrm{~h}$.

\subsubsection{Spectrophotometer and Viable Count}

Each microorganism were grown in $10 \mathrm{~mL}$ of nutrient broth with $\mathrm{GO}$ disk $(10 \mathrm{mg})$ at $30^{\circ} \mathrm{C}$ for $24 \mathrm{~h}$ under $100 \mathrm{rpm}$ shaking speed. After $24 \mathrm{~h}$. incubation the reading of turbidity for each cultures with GO for each microorganisms was record using the spectrophotometer at $600 \mathrm{~nm}$ and compared with control to monitoring the microorganisms growth and multiply of cells in liquid media. By spectrophotometer analysis the increased culture turbidity of the reading reflects the index of microbial growth and cell numbers (biomass) and the amount of transmitted light decreases as the cell population increases. The absorbance, or Optical Density (OD), was read at wavelength $600 \mathrm{~nm}$ and it gives an indirect measurement of the number of microbial population. To this purpose, the absorbance of $1 \mathrm{~mL}$ of each broth culture was measured by the spectrophotometer (JENWAY 6305 UV-VIS Spectrophotometer). The spectrophotometer measurement was made by standardizing the machine on the sterile nutrient broth with its concentration equal to zero. The spectrophotometer measurements were performed at 1, 2, 3 and 4 days of incubation with GO disk. This spectrophotometer analysis was paralleled by measurement of the loss of microorganism viability which was counted by transferred and spread of $100 \mu \mathrm{L}$ of the cultures to sterilized NA plate and incubated at $37^{\circ} \mathrm{C}$ for $24 \mathrm{~h}$. Media with GO and without bacteria was used as control.

\subsection{Scanning Electron Microscope (SEM)}

SEM was used to examine the interactions between GO disk and microorganisms cells. From each 5 different cultures $\mathrm{GO}$ disk $(5 \mathrm{~mm}$ in diameter) were examined using a scanning electron microscope (SEMEDX Philips) without any coating.

\section{RESULTS AND DISCUSSION}

\subsection{Preparation and Characterization of GO}

\subsubsection{X-ray Diffraction Analysis (XRD) of Graphite and GO}

The XRD pattern of graphite and GO are shown in Fig. 1A and $B$ respectively. As shown in XRD of graphite powder, a strong sharp reflection peak appeared at $26.52^{\circ}$ indicating a higher ordered structure, that corresponding to an interlayer spacing of about $3.35 \mathrm{~A}^{\circ}$ $(0.335 \mathrm{~nm})$. The XRD patterns of GO samples (Fig. 1B) shows that with oxidation, a formation of new broad peak at $2 \theta=10.92^{\circ}$ with interlayer spacing of about 8.09 $\mathrm{A}^{\circ}(0.809 \mathrm{~nm})$. This peak has lower intensity compared to the graphite peak. This change comes from the heterogeneous nature of the oxidized graphite. The peak of graphite $\left(26.52^{\circ}\right)$ starts decreases in $\mathrm{GO}$, due to the oxidation and this peak decreases and the appearance of a peak at $24.2^{\circ}$ is observed with interlayer spacing of $3.7018 \mathrm{~A}^{\circ}(0.37018 \mathrm{~nm})$. The observed interlayer spacing of S-3 was $3.7018 \mathrm{~A}^{\circ}(0.37 \mathrm{~nm})$, due to the presence of oxygenated functional groups and intercalated water molecules which corresponds to the GO. The XRD results of GO samples are in good agreement with the literature (Kaniyoor et al., 2010; Du et al., 2010; Gurunathan et al., 2012).

\subsubsection{Thermogravimetric Analysis (TGA)}

The TGA for graphite and GO are shown in Fig. $\mathbf{2 A}$ and $\mathbf{B}$ respectively. It is clear from the Fig. $\mathbf{2 A}$ that, graphite was thermally stable up to $600^{\circ} \mathrm{C}$. After oxidation, for GO (Fig. 2B) slight mass decrease at $177^{\circ} \mathrm{C}$ and significant decrease to $209^{\circ} \mathrm{C}$ are noticed. It shows two degradation step and maximum weight loss takes place at $231.29^{\circ} \mathrm{C}$. This was caused by loss of water molecules, loss of oxygen-containing groups and above $500^{\circ} \mathrm{C}$ relates to an unstable carbon remaining in the structure and the pyrolysis of oxygen functional groups in the main structure to yield $\mathrm{CO}$ and $\mathrm{CO}_{2}$. (Bagri et al., 2010; Fan et al., 2010; Loryuenyong et al., 2013).

Figure 3 shows the FT-IR spectrum of GO. The stretching vibrations of hydroxyl groups, O-H stretching was observed at $3489 \mathrm{~cm}^{-1}$. The peak at $1730 \mathrm{~cm}^{-1}$ shows $\mathrm{C}=\mathrm{O}$ (carbonyl/carboxy) stretching and peak at $1618 \mathrm{~cm}^{-1}$ can be assigned to the skeletal vibrations of un oxidized graphitic domains. The peak at $1300 \mathrm{~cm}^{-1}$ show for C-O (carboxy) and peak at $1238 \mathrm{~cm}^{-1}$ for C-O$\mathrm{H}$ deformation peak. The C-O stretching vibration peak shows at $1027 \mathrm{~cm}^{-1}$. All these bands related with the oxygen containing functional groups in $\mathrm{GO}$ and the presence of these oxygen-containing groups reveals that the graphite has been oxidized. The polar groups, especially the surface hydroxyl groups, result in the formation of hydrogen bonds between graphite and water molecules; this further explains the hydrophilic nature of GO (Guo et al., 2009; Shahriary and Athawale, 2014). 
Roda F. Al-Thani et al. / OnLine Journal of Biological Sciences 14 (3): 230-239, 2014

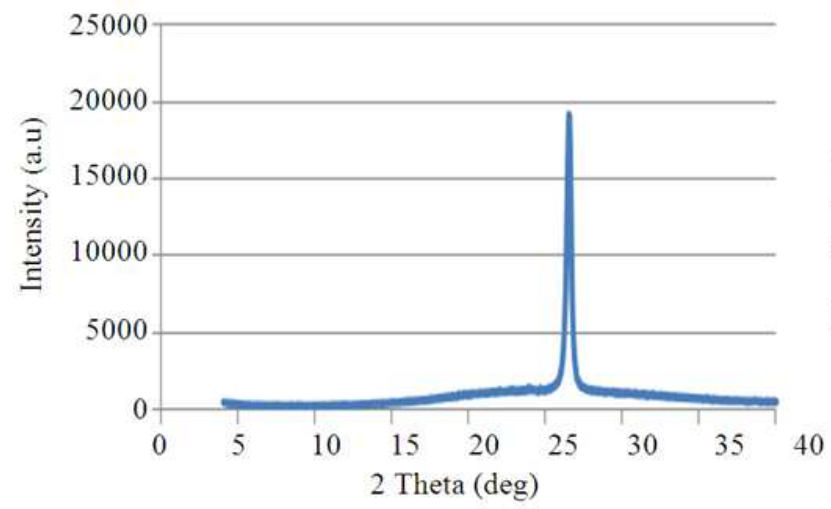

(a)

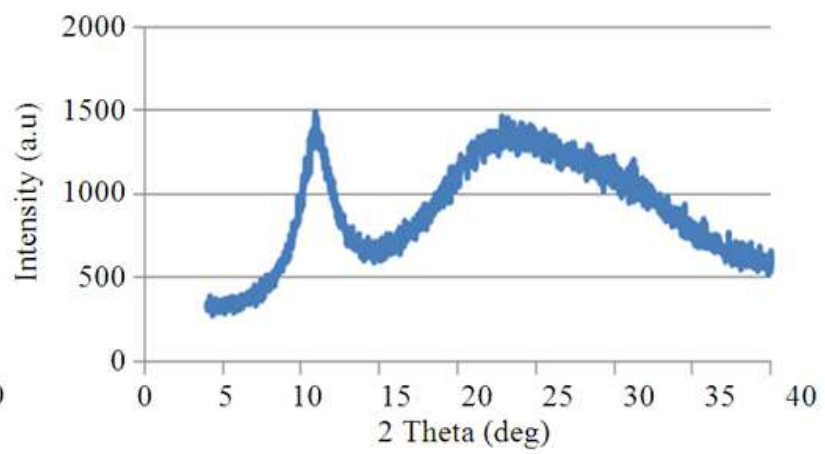

(b)

Fig. 1. XRD Patterns of graphite (A) and GO (B)

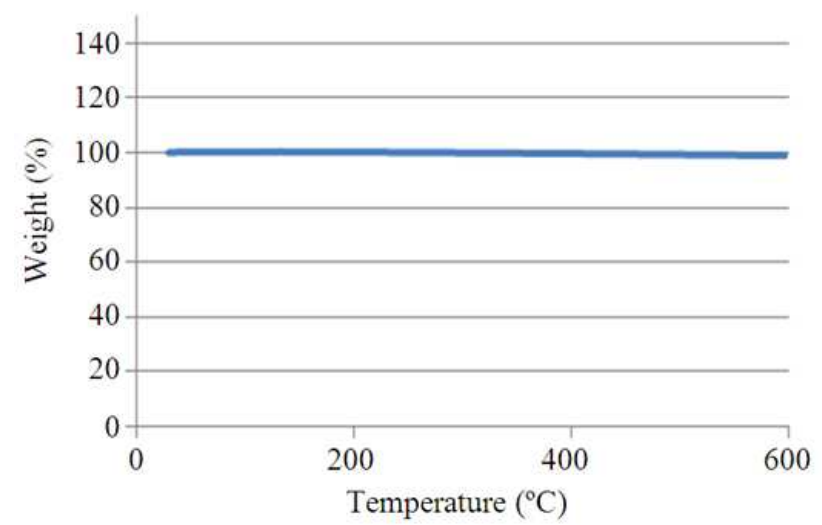

(a)

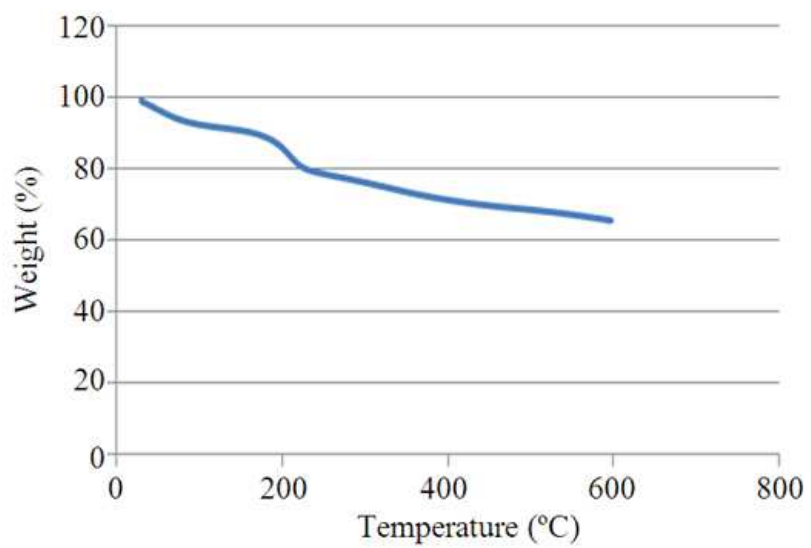

(b)

Fig. 2. TGA patterns of graphite powder (A) and GO (B)

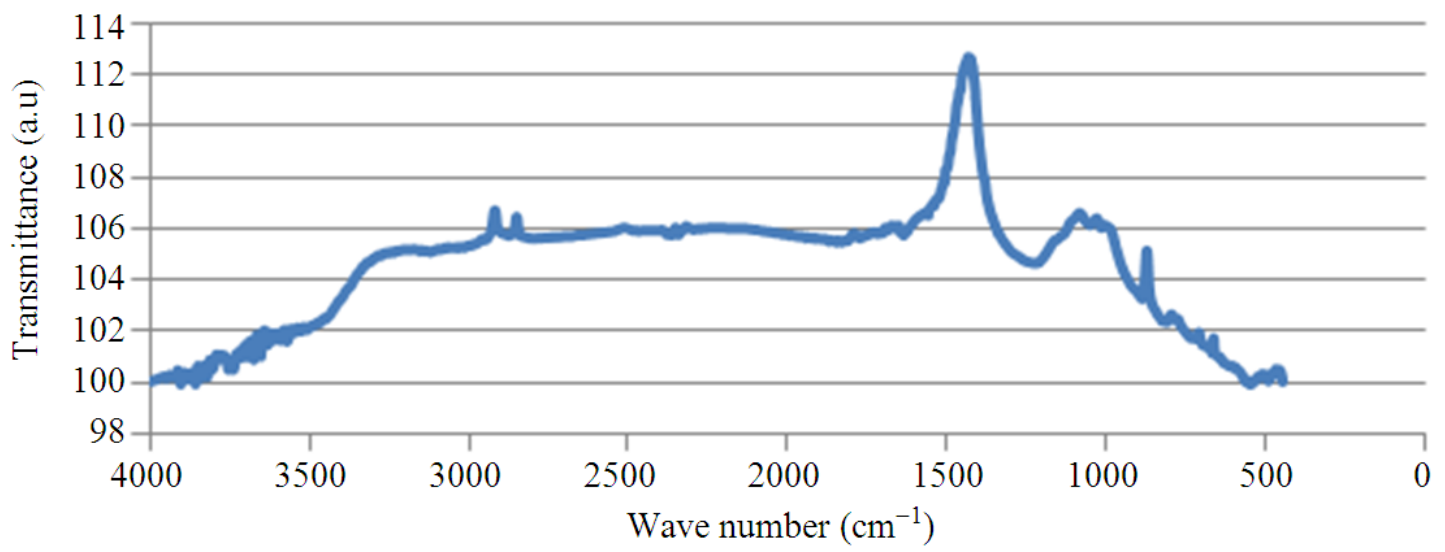

Fig. 3. FT-IR spectrum of GO 


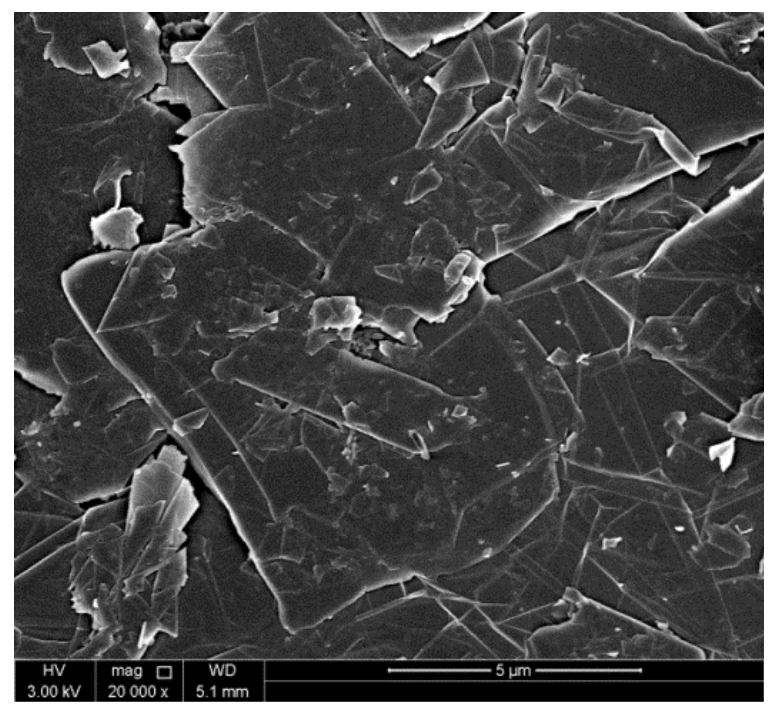

(a)

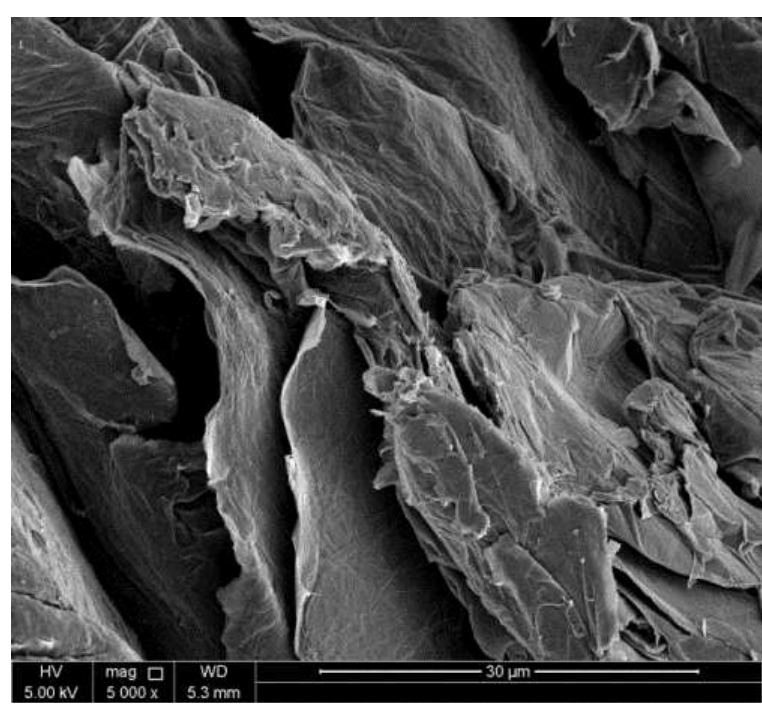

(b)

Fig. 4. SEM images of graphite powder (A) and GO (B) before incubation with the microorganisms

\subsubsection{Scanning Electron Microscope}

Figure 4A and B show the SEM images of graphite and GO respectively before incubation with the microorganisms. SEM photos of graphite shows flaky shape and irregular, thicker platelets are also present in the powder. SEM photos of GO (Fig. 4B) shows that, the exfoliated graphite particles were smaller than graphite and the sheets were smooth with small wrinkles at the edges.

\subsection{The Antimicrobial Activity of GO}

\subsubsection{Agar Diffusion}

The agar diffusion assay is a fast and simple to estimate the susceptibility of microorganisms toward an antimicrobial agent such as GO. This test is based on the diffusion of the nanomaterial from high concentrations (disk or filter paper) to the agar surface. Das et al. (2011) however, it allows only a qualitative result about the susceptibility of the microbial strain. For fast grower microorganisms such as what we used in this study, the results interpreted after $24 \mathrm{~h}$. incubation at $37^{\circ} \mathrm{C}$, if the GO has activity, clear zones (no growth of microorganism) will be observed around the disk or filter paper. The presence or absence of growth inhibition zone was interpreted as sensitive or resistant of microorganisms to the GO agent.

E. coli and $P$. aerogenosa are Gram negative bacteria, facultative anaerobic, motile, non-sporulation and cells are typically rod-shaped while S. aureus and S. faecalis are Gram positive bacteria, facultative anaerobic, non- motile, non-sporulation and cells are typically spherical-shaped. The cell wall is different between both types; Gram negative bacteria possess a thin peptidoglycan layer with another layer structured called the outer Lipopolysaccharide membrane (LPS) whereas Gram positive bacteria possess a thick peptidoglycan layer and no outer lipopolysaccharide membrane (Tortora et al., 2013). The cell wall is very important because it can serve as a resistant barrier to some particles and other cells or it can be serve as a target for many antibiotics. A cell wall lets a bacterial cell have its defining shape. The results shows that GO (both if it was apply as disk or filter paper immersed into GO solution) affected more on Gram positive bacteria, which not have the outer lipopolysaccharide membrane in their cell wall, than Gram negative bacteria and fungi (Fig. 5A and $B$ respectively).

\subsubsection{Spectrophotometer and Viable Count}

Figure 6 indicated the OD values of the growth of the 5 microorganisms incubated with $\mathrm{GO}$ at different time $(24,48,72$ and $96 \mathrm{~h})$, the OD value of a control sample (broth with GO film). This behavior confirmed the good antibacterial activity of such material. For all types of microorganisms, the growth was totally inhibited when cultured on NB with GO film. The OD 600 of microbial growth through 4 days indicated that, first and second days of incubation the growth of bacterial species was increased and not affected by GO 
but after that time the growth was stop and no increase of cells biomass which indicated antimicrobial activities of GO against those bacteria. These results compared and confirmed by the viable cell culture which give the same results with no growth after 4 days. Similar results were obtained with other researchers which also suggested that antibacterial activities of GO are time, concentration and size dependent in addition to the negatively charged membranes of bacterial cells (Liu et al., 2012; Li et al., 2014). All microbial cells used in this study have the same generation time, the time required for a cell to divide or a population to double, about $60 \mathrm{~min}$ except the $E$. coli which is about $30 \mathrm{~min}$ that why this species is very fast grow bacteria than the other (Fig. 6).

Toxic by-products known as Reactive Oxygen Species (ROS) are produced by GO, which would affect microorganisms viability. These ROS include hydrogen peroxide, superoxide anion radicals, singlet oxygen, hydroxyl radicals and nitric oxide. To help protect against the destructive effects of ROS, aerobic organisms and facultative anaerobic microorganisms produce protective antioxidant enzymes such as catalase, superoxide dismutase and glutathione peroxidase. Catalases are proteins that catalyse the conversion of Hydrogen Peroxide $\left(\mathrm{H}_{2} \mathrm{O}_{2}\right)$ to water and molecular oxygen, thereby protecting cells from the toxic effects of hydrogen peroxide. Catalases are produced by all microorganisms used in this study except $S$. faecales which is microaerophilic. Li et al (2014) suggested the antibacterial activity of graphene does not stem from ROS mediated damage, but through electron transfer interaction from microbial membrane to graphene.
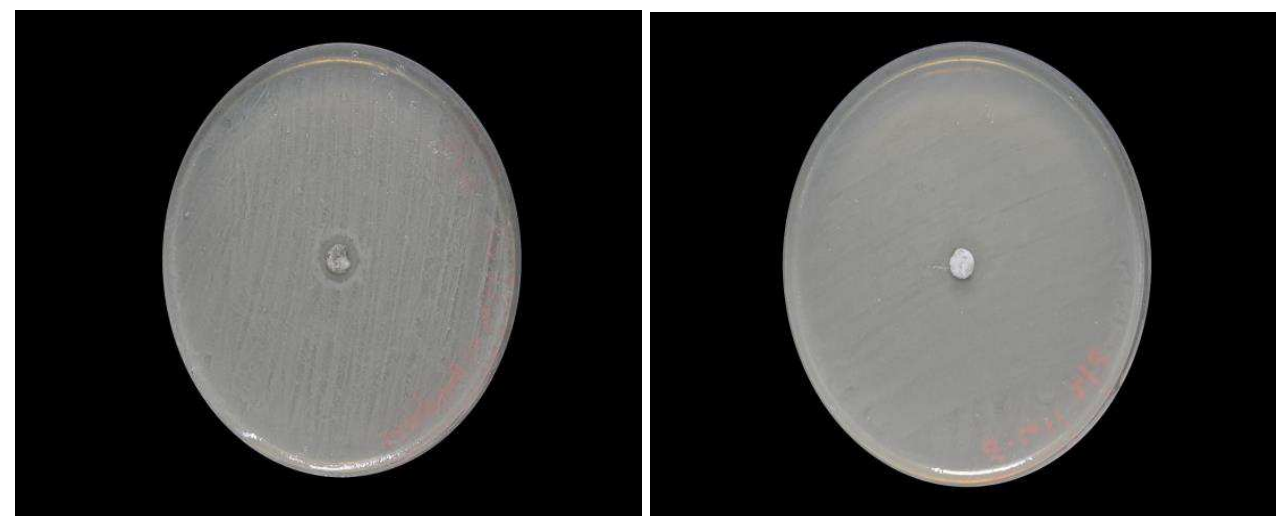

Fig. 5. Antibacterial activity of filter paper immersed into GO solution, positive result (growth inhibition zone) against $S$. aureus (A) and negative result (no growth inhibition zone) against $E$. coli (B)

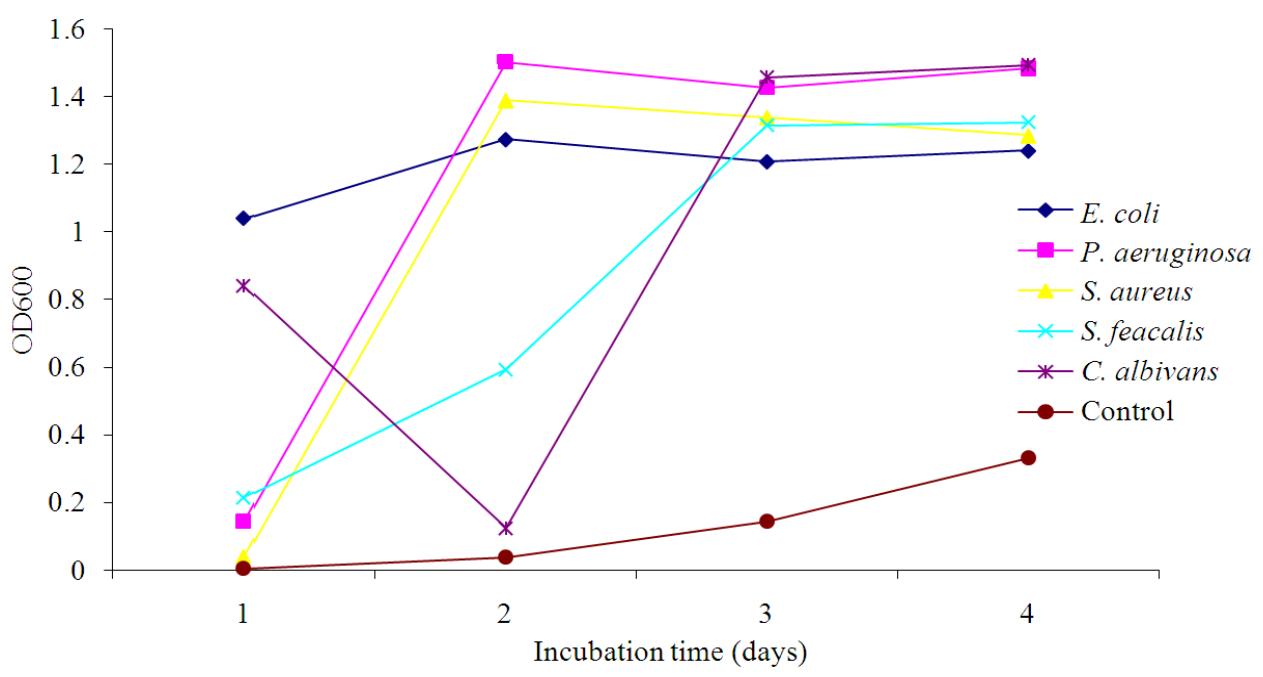

Fig. 6. The OD values of the 5 microorganisms growth incubated with GO at different time 
Roda F. Al-Thani et al. / OnLine Journal of Biological Sciences 14 (3): 230-239, 2014

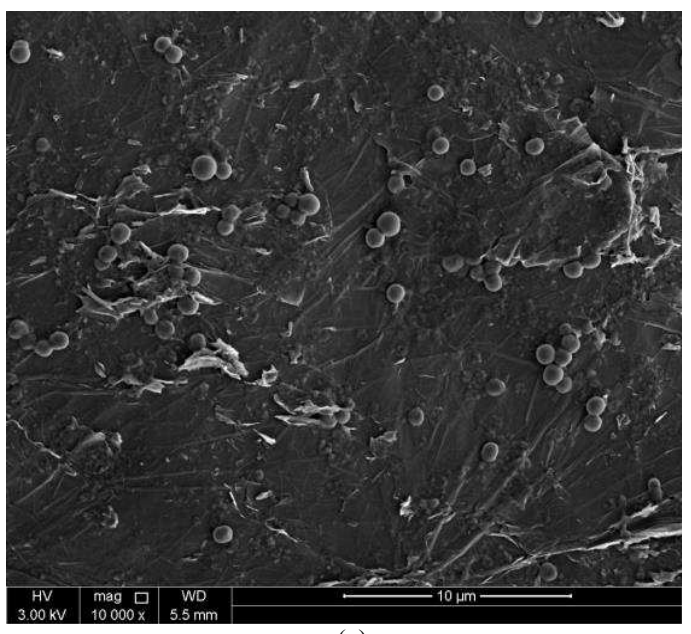

(a)

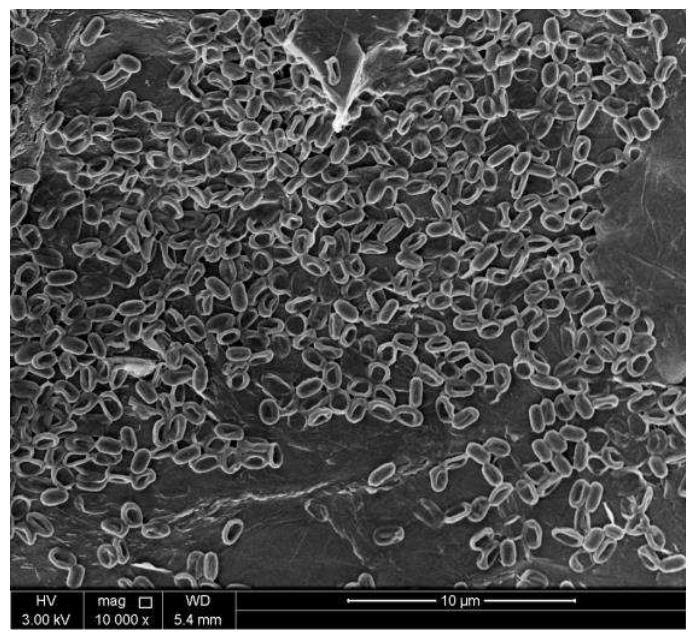

(c)

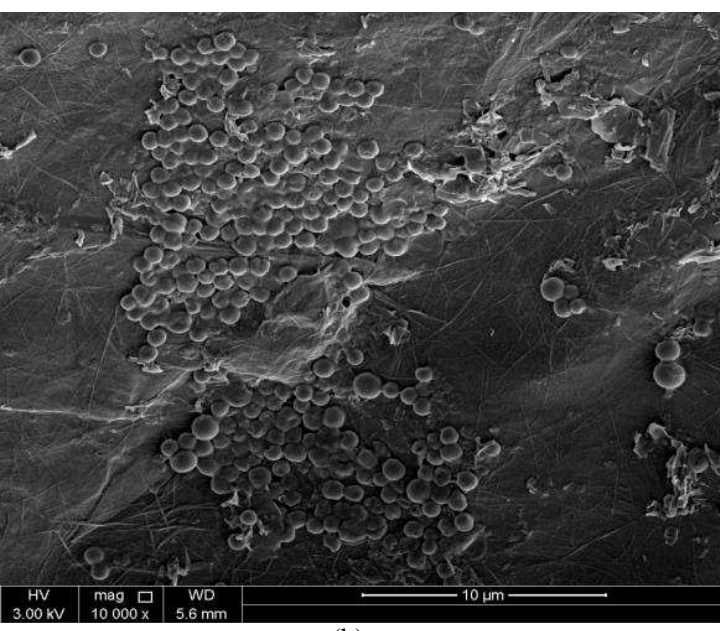

(b)

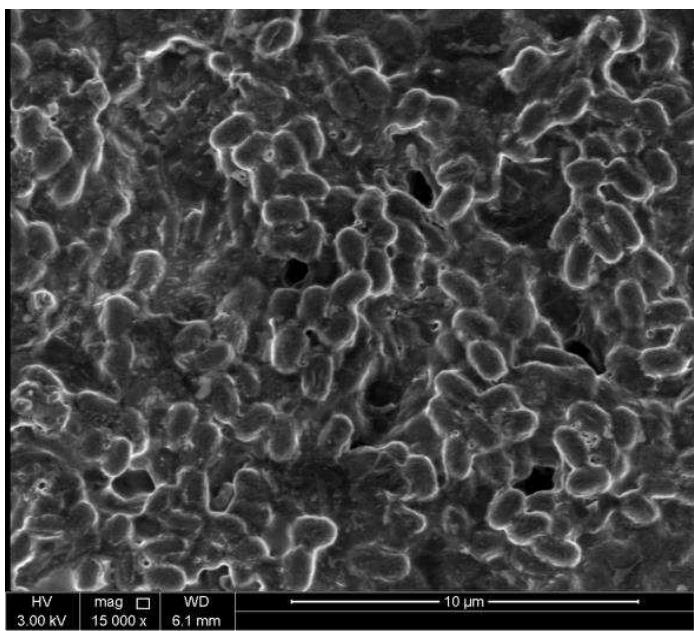

(d)

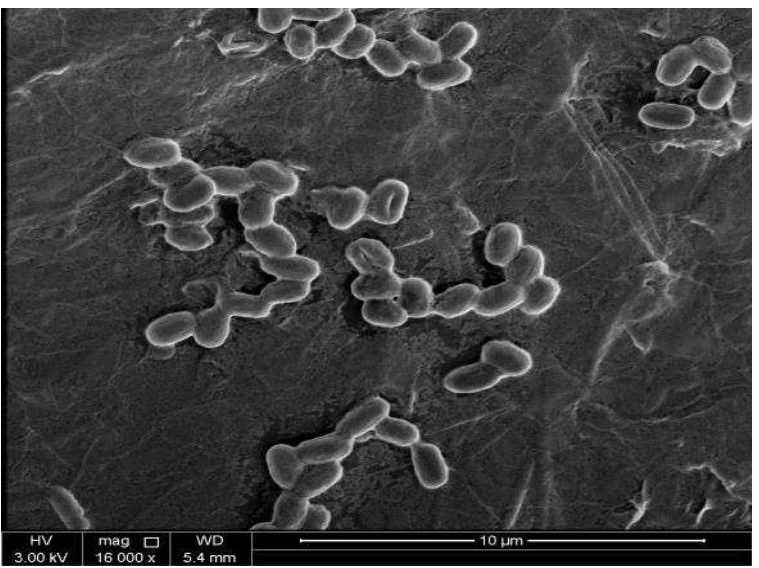

(e)

Fig. 7. SEM images of S. aureus (A), S. feacalis (B), E. coli (C), P. aeruginosa (D) and C. albicans (E) 
C. albicansis eukaryotic fungus and cell structure and metabolism are more complex than bacterial cells that why not any antimicrobial can affect or stop their growth. Li et al., (2013) found promise anti-fungal activity of GO against $C$. albicans. Figure 6 shows the loss of viability of $C$. albicansincubated with $\mathrm{GO}$ at different incubator time. The loss of viability was increased with incubation time.

\subsubsection{Scanning Electron Microscope}

The action mechanisms of antimicrobial drugs into living cell could be inhibition of cell wall synthesis or inhibition of cell membrane function or inhibition of protein synthesis or inhibition of nucleic acid synthesis (Tortora et al., 2013). To know more about the interaction between microbial cells and GO disks, SEM was used to demonstrate these interactions.

Figure 7A and B show Gram positive cells ( $S$. aureus and $S$. faecales respectively) the morphologies of most of the survived cells remained unchanged with round shape and smooth surface, no cell divided within demonstrating at SEM images which indicted the inhibition of cell division of those cells by the GO. Figure 7C and D show that most of Gram negative cells (E. coli and P. aerogenosa) become flattened wrinkled and damaged and lose their integrity after exposure to GO. The destruction of cells in SEM images is consistent with previous images obtained by scanning electron microscope (Tang et al., 2013). Figure 7E demonstrate the $C$. albicans cells with less effective, the reason why the GO was less effective to inhibit the fungi cells, is probably due to the cell walls type of fungi. The structure and metabolism of fungal cells are more complex and resistant to antimicrobial and to high osmotic pressure.

In addition to the cell wall bacteria secrete a variety of Extracellular Polymeric Substances (EPS), including polysaccharides, proteins and nucleic acids that vary in molecular mass and structural properties (Notley et al., 2013). Figure 7B and D indicated EPSs as attached capsular polysaccharides and as free polysaccharides released into the growth medium. This layer acts as affording the cell proytection from major bacterial pathogens, play a major role in the bacterial colonization of surfaces, biotic and abiotic, by enabling cell adhesion and co-aggregation via dipole interactions, covalent or ionic bonding, steric interactions and hydrophobic association, making the target surface more attractive for bacterial attachment.

\section{CONCLUSION}

This study demonstrates the preparation of GO by using modified Hummers method and characterization results confirm the $\mathrm{GO}$ formation. We studied the antimicrobial activity of prepared GO toward four prokaryotic bacterial species and one eukaryotic fungal species. All microorganisms used in this study are common, can cause disease in animals, including humans and can be found in soil, water, skin flora and colonized many natural and artificial environments. All microbial tests were carried out with different timings for every 24 h. The developed GO exhibit excellent antimicrobial property and GO affects more on Gram positive bacteria than Gram negative bacteria. The cell growth was decrease with the increase of the incubation time. The antimicrobial activates may be attributed to membranes disruption or stop cell division or oxidative stress, which leads the cell death. GO inhibits the microbial growth which prove that GO is useful as anti-microbial agent for different microorganisms. The cell death was lower in $C$. albican when compare with bacteria because these types of cells are more complex in there structures and metabolism than prokaryotic bacterial cells. The emergence of antibiotic-resistant strains of pathogenic bacteria is a universal problem in clinical medicine and can cause life-threatening infections in humans, especially in the nosocomial environment So it is very important to look for more materials that can be used as antimicrobial agents in addition to focus in and studies the mechanisms of interactions between GBMs and different living prokaryotic and eukaryotic cells to concern the potential impact of graphene and its derivatives on humans and environmental health. Also further investigations necessary to understand the molecular basis of GO action and genetic materials of microbial cells (mutation, expression and resistant genes).

\section{ACKNOWLEDGMENT}

This study is supported by QF/NPRP fund for project titled "Tailored Structuring and Properties of PolymerGraphene and Polymer-Graphite Nanoplateletes Composites". The authors would like to thank the Department of Health Sciences at Qatar University for microorganisms cultures.

\section{REFERENCES}

Akhavan, O. and E. Ghaderi, 2010. Toxicity of graphene and graphene oxide nanowalls against bacteria. ACS Nano., 4: 5731-5736. DOI: 10.1021/nn101390x 
Akhavan, O. and E. Ghaderi, 2012. Escherichia coli bacteria reduce graphene oxide to bactericidal graphene in a self-limiting manner. Carbon, 50: 1853-1860. DOI:10.1016/j.carbon.2011.12.035

Alves, O.L., C.M. Ana de Moraes, M.B. Simoes, L.C. Fonseca and R.O. do Nascimento et al., 2014. Nanomaterials. In: Nanomedicine and Nanotoxicology, Duran, N., S.S. Guterres and O.L. Alves (Eds.)., Springer, New York, pp: 1-29.

Bagri, A., C. Mattevi, M. Acik, Y.J. Chaba and M. Chhowalla et al., 2010. Structural evolution during the reduction of chemically derived graphene oxide. Nat. Chem.. 2: 581-587. DOI: 10.1038/NCHEM.686

Bykkam, S., V.K. Rao, S.C.H. Chakra and T. Thunugunta, 2013. Synthesis and characterization of graphene oxide and its antimicrobial activity against Klebseilla and Staphylococcus. Int. J. Adv. Biotech. Res., 4: 142-146.

Chen, J., X. Wang and H. Han, 2013. A new function of graphene oxide emerges: Inactivating phytopathogenic bacterium Xanthomonas oryzae pv. Oryzae. J. Nanopart. Res., 15: 1658-1672. DOI: $10.1007 / \mathrm{s} 11051-013-1658-6$

Das, M.R., R.K. Sarma, R. Saikia, V.S. Kale and P.S. Shelke et al., 2011. Synthesis of silver nanoparticles in an aqueous suspension of graphene oxide sheets and its antimicrobial activity. Colloids Surfaces B, 83: 16-22. DOI:10.1016/j.colsurfb.2010.10.033

De Faria A.F., A. C. M. de Moraes and O. L. Alves, 2014. Toxicity of Nanomaterials to Microorganisms: Mechanisms, Methods, and New Perspectives. In: Nanomedicine and Nanotoxicology, Duran, N., S.S. Guterres and O.L. Alves (Eds.)., Springer, New York, pp: 363-405.

Du, Q., M. Zheng, L. Zhang, Y. Wang and J. Chen et al., 2010. Preparation of functionalized graphene sheets by a low-temperature thermal exfoliation approach and their electrochemical supercapacitive behaviors. Electrochim. Acta, 55: 3897-3903. DOI: 10.1016/j.electacta.2010.01.089

Fan, Z., K. Wang, T. Wei, J. Yan and L. Song et al., 2010. An environmentally friendly and efficient route for the reduction of graphene oxide by aluminum powder. Carbon, 48: 16861689. DOI: 10.1016/j.carbon.2009.12.063

Geim, A.K. and K.S. Novoselov, 2007. The rise of graphene. Nat. Mater., 6:183-191. DOI: $10.1038 /$ nmat 1849
Gurunathan, S., J.W. Han, A.A. Dayem, V. Eppakayala and J.H. Kim, 2012. Oxidative stress-mediated antibacterial activity of graphene oxide and reduced graphene oxide in Pseudomonas aeruginosa. Int. J. Nanomed., 7: 5901-5914. DOI: 10.2147/IJN.S37397

Gurunathan, S., J.W. Han, V. Eppakayala and J. Kim, 2013. Microbial reduction of graphene oxide by Escherichia coli: A green chemistry approach. Colloids Surfaces B, 102: 772-777. DOI: 10.1016/j.colsurfb.2012.09.011

Guo, H.L., X.F. Wang, Q.Y. Qian, F.B. Wang and X.Y. $\mathrm{Xia}, 2009$. A green approach to the synthesis of graphene nanosheets. ACS Nano, 3: 2653-2659. DOI: $10.1021 / \mathrm{nn} 900227 \mathrm{~d}$

Hu, W.B., C. Peng, W.J. Luo, M. Lv and X.M. Li et al., 2010. Graphene-Based Antibacterial Paper. ACS Nano. 4: 4317-4323. DOI: 10.1021/nn101097v

Kaniyoor, A., T.T. Baby and S. Ramaprabhu, 2010. Graphene synthesis via hydrogen induced low temperature exfoliation of graphite oxide. J. Materials Chem., 20: 8467-8469. DOI: 10.1039/C0JM01876G

Khanra, P., T. Kuila, N.H. Kim, S.H. Bae and D. Yu et al., 2012. Simultaneous bio-functionalization and reduction of graphene oxide by baker's yeast. Chem. Eng. J., 183: 526-533. DOI: 10.1016/j.cej.2011.12.075

Li, C., X. Wang, F. Chen, C. Zhang and X. Zhi et al., 2013. The antifungal activity of graphene oxidesilver nanocomposites. Biomaterials., 34: 38823890. DOI: 10.1016/j.biomaterials.2013.02.001

Li, J., G. Wang, H. Zhu, M. Zhang and X. Zheng et al., 2014. Antibacterial activity of large-area monolayer graphene film manipulated by charge transfer. Scientific Rep., 4: 4359-4367. DOI: 10.1038/srep04359

Lim, H.N., N.M. Huang and C.H. Loo, 2012. Facile preparation of graphene-based chitosan films: Enhanced thermal, mechanical and antibacterial properties. J. Non-Crystalline Solids, 358: 525530. doi:10.1016/j.jnoncrysol.2011.11.007

Liu, S., T.H. Zeng, M. Hofmann, E. Burcombe, J. Wie, R. Jiang, J. Kong and Y. Chen, 2011. Antibacterial activity of graphite, graphite oxide, graphene oxide and reduced graphene oxide: Membrane and oxidative stress. ACS Nano, 5: 6971-6980. DOI: $10.1021 / \mathrm{nn} 202451 \mathrm{x}$ 
Liu, S., M. Hu, T.H. Zeng, R. Wu and R. Jiang et al., 2012. Lateral dimension-dependent antibacterial activity of graphene oxide sheets. Langmuir, 28: 12364-12372. DOI: 10.1021/1a3023908

Loryuenyong, V., K. Totepvimarn, P. Eimburanapravat, W. Boonchompoo and A. Buasri, 2013. Preparation and characterization of reduced graphene oxide sheets via water-based exfoliation and reduction methods. Adv. Materials Sci. Eng.. 2013: 923403-923407 . DOI: $10.1155 / 2013 / 923403$

Notley, S.M., Russell J.C. and E.P. Ivanova, 2013. Bacterial Interaction with Graphene Particles and Surfaces, Nanotechnology and Nanomaterials, In: Advances in Graphene Sciences. Aliofkhazraei, M. (Ed.)., ISBN 978-953-51-1182-5.

Sanchez, V.C., A. Jackhak, R.H. Hurt and A.B. Kane, 2011. Biological interactions of graphene-family nanomaterials: an interdisciplinary review. Chem. Res. Toxicol., 25: 15-34. DOI: $10.1021 / \mathrm{tx} 200339 \mathrm{~h}$

Santos, C.M., J. Mangadlao, F. Ahmed, A. Leon and R.C. Advincula et al., 2012. Graphene nanocomposite for biomedical applications: fabrication, antimicrobial and cytotoxic investigations. Nanotechnology, 23: 395101395101. DOI: 10.1088/0957-4484/23/39/395101
Shahriary, L. and A. Athawale, 2014. Graphene oxide synthesized by using modified hummers approach. IJREEE., 2: 58-63.

Tang, J., Q. Chen, L. Xu, S. Zhang and L. Feng et al., 2013. Graphene oxide-silver nanocompositeas a highly effective antibacterial agent with speciesspecific mechanisms. ACS Appl. Mater. Interfaces., 5: 3867-3874. DOI: 10.1021/am4005495

Tortora, G.J., B.R. Funke and C.L. Case, 2013. Microbiology: An Introduction. 11th Edn., Pearson Benjamin Cummings, San Francisco.

Wang, G.M., F. Qian, C.W. Saltikov, Y.Q. Jiao and Y. $\mathrm{Li}, 2011$. Microbial reduction of graphene oxide by shewanella. Nano. Res., 4: 563-570. DOI: 10.1007/s12274-011-0112-2

Zhang, Y.B., S.F. Ali, E. Dervishi, Y. Xu, and Z.R. Li et al., 2010. Cytotoxicity effects of graphene and single- wall carbon nanotubes in neural phaeochromocytoma-derived PC12 cells. ACS Nano, 4: 3181-3186. DOI: 10.1021/nn1007176

Zheng, L., D. Ye, L. Xiong, J. Xu and K. Tao et al., 2013. Preparation of cobalttetraphenylporphyrin/reduced graphene oxide nanocomposite and its application on hydrogen peroxide biosensor. Analyticachimicaacta, 768: 69-75. DOI: 10.1016/j.aca.2013.01.019 